Western University Scholarship@Western

Economic Policy Research Institute. EPRI Working

Papers

Economics Working Papers Archive

2005

2005-02 Keynes and the Birth of Modern

Macroeconomics

David Laidler

Follow this and additional works at: https://ir.lib.uwo.ca/economicsepri_wp

Part of the Economics Commons

Citation of this paper:

Laidler, David. "2005-02 Keynes and the Birth of Modern Macroeconomics." Economic Policy Research Institute. EPRI Working Papers, 2005-2. London, ON: Department of Economics, University of Western Ontario (2005). 


\title{
Keynes and the Birth of Modern Macroeconomics
}

by

David Laidler

Working Paper \# 2005-2

February 2005

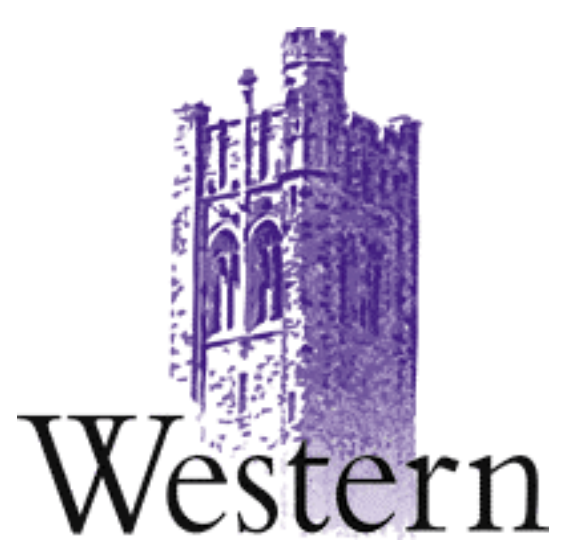

\section{RBC Financial Group \\ Economic Policy Research Institute EPRI Working Paper Series}

\author{
Department of Economics \\ Department of Political Science \\ Social Science Centre \\ The University of Western Ontario \\ London, Ontario, N6A 5C2 \\ Canada
}

This working paper is available as a downloadable pdf file on our website http://www.ssc.uwo.ca/economics/centres/epri/ 


\section{Keynes and the Birth of Modern Macroeconomics ${ }^{1}$}

by

\section{David Laidler}

Abstract: The usual description of Keynes's macroeconomics as relying on the postulate of money wage stickiness to explain unemployment, and advocating fiscal policy as its cure, is largely mythical. Rather he was concerned with exploring the theoretical idea that an economy co-ordinated by monetary exchange is prone to market failures that create unemployment. The origins of this idea in what Keynes' called "classical" economics can be traced back at least as far as John Stuart Mill, though he himself preferred to claim the much less orthodox Malthus as his antecedent. Be that as it may, Keynes's own emphasis on income and employment variations as the both the result of and the "solution" to specifically inter-temporal failures was highly original. The idea that monetary exchange might involve co-ordination failures of any sort has now largely disappeared from macroeconomics, under the influence of New-classical economics.

Keywords: macroeconomics, Keynesian economics, markets, money, interest rates, unemployment, multiplier..

JEL Classification: B12, B22, B31.

${ }^{1}$ This paper has been prepared for inclusion in Roger Backhouse and Bradley Bateman (eds.) The Cambridge Companion to Keynes, Cambridge University Press (forthcoming) I am grateful to the editors and to Peter Howitt, Angela O’Mahony and Hans-Michael Trautwein for comments on earlier versions of this paper. 


\section{I - Keynes and Macroeconomics}

Keynes’s (1936) General Theory of Employment, Interest and Money was about the role of the monetary system in general, and the rate of interest in particular, in causing the overall level of employment in a market economy to fall short of its full potential. A sub-set of its ideas were systematised by a younger generation of economists and introduced to the textbooks, just as the word macroeconomics began to be widely used to distinguish the analysis of the economy as a whole from microeconomics which dealt with individual households, firms or even industries. Not without justification, macroeconomics soon became a synonym for Keynesian economics; and in the late1970s, when the influence of Keynes's specific ideas on the sub-discipline had long since waned, he was still commonly credited with having founded it. (Lucas and Sargent, 1978)

\section{II - Myths about Keynes and the Classics}

Myth-making about Keynes's role in the creation of modern macro-economics began with his own 1936 account of the work of his predecessors and older contemporaries, to whom he affixed the blanket label the Classical Economists. He attributed a fundamental weakness to their economic theory: namely, that it encompassed the postulate - known as Say's Law - that an economy-wide excess supply of output and therefore of labour was a logical impossibility, and that it was incapable of explaining economy-wide unemployment.

Keynes’ account of Classical economics was a caricature, but most of his interpreters accepted it, and supplemented it with distortions of his own work to produce a myth about the development of macroeconomics that still dominates many economists' beliefs. In this myth, Classical economics argued that, if more people sought work than there were jobs available, a fall in wages would not only suffice to restore full employment, but would in fact occur. The relevant wage was the real wage, the nominal wage adjusted for variations in the purchasing power of the money in terms of which it was actually set, but, so the myth continued, the Classical economists had failed to notice that, in the modern world, a wide variety of contractual rigidities prevented nominal wages from falling in the face of an excess supply of labour. Keynes, however, did notice this, deduced that real wages could therefore not be relied on to adjust according to Classical principles. He proposed that, in these circumstances, the government should fight unemployment by increasing its own spending on goods and services, and perhaps by cutting taxes to encourage households to increase their spending, and should be prepared to run budget deficits to finance such measures.

According to this myth, then, Keynes’s originality in 1936 lay first in recognising that the labour market was subject to wage rigidities that other economists had overlooked; and second in proposing that unemployment resulting from these rigidities be dealt with by an active program of deficit spending by governments. This simple tale is implausible. It is unlikely that economists, whose discipline had existed since at least the second half of the $18^{\text {th }}$ century, had failed to notice so salient a feature of labour markets as wage stickiness in the intervening years, 
and it is hard to see, for example, where the first Roosevelt administration's New Deal could have come from, if Keynes was not to invent expansionary fiscal policy until1936. Finally, if this is nevertheless what Keynes' book was really about, why did he not give it some such title as Employment, Wages and Fiscal Policy? After all, the above account credits it with only superficial theoretical content, and mentions neither interest nor money at all.

\section{III - Say’s Law and Money}

Keynes's caricature of Classical economics nevertheless captured certain salient features of its subject. For a century after the publication of the Wealth of Nations, (Smith 1776) its centrepiece was a theory of economic growth that was indeed underpinned by a version of Say's Law. Smith had argued that income not spent by landowners and capitalists on consumption, and hence saved, would be channelled into supporting labour in the production of goods for future consumption, and that, therefore, there would be no chance of output going to waste. With certain qualifications having to do with the production of machinery, David Ricardo (1817, 1821) also subscribed to this view. More generally, he also argued that, though goods were not bartered, but bought and sold in exchange for money, monetary exchange was purely an intermediate activity that did not alter the essential nature of market activity, namely that it was goods and services that ultimately bought goods and services, so that a general oversupply of them, and hence of labour, was impossible.

Ricardo, however, wrote in the second decade of the $19^{\text {th }}$ century, a period marked by unemployment and social unrest, and some commentators, notably his friend Thomas Malthus (1820), attributed these problem to a flaw in the mechanisms of economic growth that somehow caused rapid capital accumulation and output growth to outrun the capacity of effective demand to absorb it, leading to a general glut of commodities on the market. Ricardo's counter-argument to this, namely that unemployment reflected a mis-allocation of labour among industries brought about by post-war changes in the structure of demand, and would in due course be cured by an adjustment of relative prices, is generally judged to have carried this debate, but the dissenting position never quite died out, subsequently enabling Keynes to claim - whether accurately or not is another matter, though Steven Kates (1994) mounts a strong defence of Keynes's claim - that his General Theory was but the latest, but finally a logically coherent, manifestation of it.

Had there been no more to Classical economics than the views expressed in Ricardo's Principles, there would be much to be said for Keynes’s 1936 critique. However it also encompassed a more pragmatic literature, dealing with cyclical economic instability, which has a strong claim to be treated as the true antecedent of modern macroeconomics, and to which, incidentally, Ricardo was also an early contributor. It was in this context that John Stuart Mill $(1844,1848)$ pointed to an essential role for money in qualifying Say's law as it was generally understood, explicitly connecting his insights to the Malthus-Ricardo debate. Mill re-affirmed the impossibility of excessive capital accumulation creating a general glut of output, but noted that the proposition that agents would always bring goods and services to market with a view to buying other goods and services was true of logical necessity only in an economy where trade 
was by barter. Under monetary exchange, agents might sometimes try to sell goods to acquire money for its own sake, and when they did, there would be a general over-supply of goods on the market relative to money.

Mill associated such behaviour with financial crises. He thought that a desire to accumulate cash at such times was a reaction to acute uncertainty about the near-term future, and would be short-lived; and he did not make any more of his insights than this. But those insights were nevertheless of profound theoretical importance: they suggested that markets where exchange was mediated by money could sometimes behave in ways that would be impossible under barter, and that such behaviour stemmed from the uncertainty to which economic activity co-ordinated by monetary exchange was subject. In short, they suggested that monetary exchange was anything but an inessential feature of the economy. Much generalised and their potential implications worked out in great detail, these insights would ultimately inform the General Theory.

\section{IV - Money Wage Stickiness}

Even so, when Mill's successors began to study unemployment, they did not directly associate it with the efforts of agents to build up their money-holdings, but began to rely instead on nominal wage stickiness. Following Alfred Marshall and Mary Marshall (1879), it was often argued that, when, over the course of the cycle, the price level rose and fell, money wages would follow only sluggishly, so that real wages would fall and rise, inducing fluctuations in the demand for labour and therefore employment. ${ }^{2}$ Post-1936 myths were thus badly wrong to suggest that nominal wage stickiness as an explanation of unemployment was original to Keynes. On the contrary, in 1936 he pointed to a serious logical incompleteness in the above argument, which seemed to imply that the implementation of nominal wage cuts, a policy to which he had been strongly opposed from the mid-1920s onwards, were a sure cure for unemployment.

This incompleteness arose because the argument assumed that the demand for labour varied inversely with the real wage, a relationship that would hold for an individual firm, or even a single industry, but not necessarily for the economy as a whole. Here, a sequence of effects running from fluctuations in employment to incomes, from incomes to expenditure, and from expenditure to the demand for labour and hence back to employment, had to be taken into account. In fact, Keynes asserted, there might be no way to restoring full employment to an economy by money wage cuts. Their implementation might set in motion a downward spiral of wages and prices, with no well-determined effect on quantities. He treated this last conclusion as a logical possibility, however, not a necessity, because, as we shall now see, he did recognise

${ }^{2}$ This is not a claim that the Marshalls originated the idea of wage stickiness. It had appeared on and off in earlier literature, notably Henry Thornton (1802), but the Marshalls do seem to have been the first to deplpy it in the specific context of cyclical variations in unemployment. 
the existence of a mechanism whereby money wage cuts, whether market or policy induced, might indeed cause employment to rise.

An essential component of Keynes’s (1936) theory was that employment depended on the economy-wide demand for labour, which in turn depended on effective demand, the economy wide volume of expenditure on goods and services. He claimed that this insight had informed Malthus' theory of the general glut, but that the concept of effective demand had been lost sight of in the wake of Ricardo's victory in their debate, only now to be rediscovered by himself. He argued that money wage cuts might cure unemployment, not because they would lead to lower real wages, but because they might increase in effective demand. ${ }^{3}$ Such cuts would reduce firms' costs, enabling them to reduce prices, hence causing the general price level to fall. If the stock of nominal money in circulation was held constant as this happened, then its real purchasing power would increase, agents would find their money holdings excessive, their expenditure on goods and services would go up, and employment would therefore increase; and this would happen even though downward pressure on prices would tend to mute any direct effects on real wages.

Where the Marshalls and their successors had explained unemployment as the consequence of money wage stickiness in the face of falling prices, then, Keynes stressed that a failure of prices to fall induced by money wage stickiness could force output and employment (rather than the price level) to bear the burden of adjustment to a discrepancy between the supply and demand for money. He noted that wage cuts might, therefore, help to reduce unemployment, but he presented this effect as an unreliable one on which any case for attempting to reduce unemployment by inducing money wage cuts would nevertheless have to rely. It might, for example, be overwhelmed by depressing expectational effects on effective demand, associated with a falling (as opposed to a lower) price level, and it might be short-circuited by a monetary policy regime that permitted the nominal money supply to contract as the price level fell. Furthermore, in Keynes's view, the experience of the United States in the early years of the Depression, when the price level fell dramatically, ruled out wage-price stickiness as a plausible explanation of the occurrence of large-scale unemployment, and wage cuts as a reliable cure for it.

Keynes concluded that increasing the supply of money was a better remedy for unemployment than money wage cuts, but he had little more enthusiasm for this alternative. Rather, he argued that the causes of unemployment lay deeper in the mechanisms of monetary exchange than the effects of wage and price frictions on the workings of markets for currently produced goods and services, and that neither wage flexibility nor simple monetary measures would reliably counter them.

${ }^{3}$ Here Keynes overstated his own originality. The concept of effective demand, and the term itself, was central to Ralph Hawtrey's discussions of cyclical fluctuations from (1913) onwards. He developed a special case of the analysis which Keynes would present as novel in (1936). On this, see David Laidler (1999) 


\section{V - Saving and Investment, Uncertainty and the Monetary System}

When Adam Smith (1776) argued that a decision to abstain from current consumption (to save) was simultaneously a decision to employ labour in the production of goods for future consumption (and hence to invest), he was thinking of a choice made by an individual capitalist about the allocation over time of his own income. By Keynes's time, however, it had been a commonplace for more than a century that saving and investment decisions were typically made by different agents, and that the co-ordination of their choices about the inter-temporal allocation of resources was a task for the capital market, in which the relevant equilibrating price was the rate of interest. By then too, it had long been agreed that the rate of interest that investors were willing to pay for borrowed funds derived from their expectations about the profitability of the investments that they intended to make, and that the rate that lenders demanded depended upon their assessment of the sacrifices involved in deferring current consumption into the future. Within this broad consensus, however, the Classical literature accommodated many important variations in the its treatment of the interactions of saving and investment. One of these felicitously called The Wicksell Connection by Axel Leijonhufvud (1981) - focussed on the role of the monetary system in these matters, and is worth particular attention at this point.

Gold coinage and notes convertible into gold played a subordinate role in the late $19^{\text {th }}$ century monetary system. It was dominated by commercial banks whose lending created, as a by-product, deposits that were then used as a means of exchange. Of course, the role of banks in the monetary system had been much discussed throughout the century, but Knut Wicksell's Interest and Prices (1898) brought a new element to its analysis. Instead of concentrating on banks' capacity to create means of exchange per se, he focussed on the effects on prices of the rate of interest at which they made loans, the market rate, and its interaction with the natural rate, which he usually identified with the rate of interest which would equilibrate the savings and investment at a full employment level of output, and sometimes with the marginal productivity of capital. ${ }^{4}$

The banking system, Wicksell saw, was capable of keeping the market rate of interest away from the natural rate because of its capacity to create and destroy credit, and hence induce variations in the rate of flow of lending in the capital market that were independent of the economy's underlying saving rate. For him, the main point was that any discrepancy between these rates would have inflationary or deflationary consequences for the price level. By the 1920s, however, Wicksell's successors were beginning to stress that, if the actions of the banks

${ }^{4}$ The potential incompatibility of these two concepts of the natural rate gave rise to much discussion in the 1920s and 1930s. See Laidler 1999, Part 2, for a discussion of this matter, which is of marginal importance in the current context. 
in creating and destroying credit could prevent the rate of interest settling at its natural level, a monetary economy could offer no guarantee that decisions about saving would always and automatically be translated into matching decisions about investment, that Say's law would thus be violated, and that things perhaps could go badly wrong on the employment front.

In his (1930) Treatise on Money Keynes tried to create a theory of the business cycle partly, but explicitly, grounded in Wicksell's analysis. His basic thesis was that cyclical fluctuations stemmed from swings in investment that were in turn driven by variations in investors' perceptions of the profitability of investment. In times of optimism, the natural rate of interest rose, and in times of pessimism it fell, and the market rate of interest failed to keep up with its fluctuations. Even in the Treatise, Keynes's discussions of investors' perceptions stressed that they were influenced as much by psychology as by rational calculation, but he pushed this theme further in the General Theory, where he argued explicitly that investment was dominated by what he called "animal spirits". Though investors might act with a view to maximising the present value of an expected flow of profits, and to that extent act rationally, the expectations on which they had to base their decisions, each one of which was likely to have unique features, could rely only to a very limited extent on hard information about their likely outcomes. Hence the calculus of probabilities could not be applied to the analysis of investment decisions, and they were bound to be dominated by psychology.

Some commentators trace Keynes views on investment to ideas about fundamental uncertainty that he developed in his (1921) Treatise on Probability. However, as Bradley Bateman (1996) has noted, Keynes downplayed the importance of uncertainty in economic life in many of his writings in the 1920s, so this link is at best indirect. It is just as likely that Keynes's 1936 view of investment derived from the earlier work of his Cambridge colleagues, notably Arthur Pigou and Frederick Lavington, for as both Bateman and Laidler (1999) have pointed out, they raised such issues in the explicit context of business cycle theory in (1912) and (1922) respectively. They had argued that the longer the horizon of any investment decision, the more prone to error did it become, and that errors of optimism and pessimism alike would be correlated across agents, and have market consequences which caused them to feed on themselves over time. Thus, they had postulated that successive waves of optimism and pessimism underlay the business cycle, in a manner that to some extent anticipated Keynes's treatment in the Treatise, albeit without the latter's explicitly Wicksellian monetary apparatus.

The discussion of investment in the General Theory is supplemented by a lengthy and justly famous account of why the characteristics of modern financial markets make the problems to which the foregoing arguments point worse rather than better. According to this account, access to markets in which shares may be actively and easily traded, in which there exists considerable liquidity, enables agents to make their savings available for investment without simultaneously having to tie them up for long periods in specific projects. Though this might encourage savings, it also ensures that short-term prospects for gains and losses in financial markets will come to dominate decisions about how to hold existing wealth, and how to allocate new saving, thus ensuring that these choices remain disconnected from any careful assessment of the long term prospects for particular investment projects 
Keynes's theory of liquidity preference was also developed in the Treatise before being given a crucial role in the General Theory, and is closely related to his scepticism about the capacity of financial markets to co-ordinate saving and investment in a world characterised by uncertainty. Alfred Marshall (1871) had argued that agents desire to keep by them a certain stock of money, which represents readily available and general purchasing power, in order to facilitate their transactions in markets for goods and services, and so matters had stood in Cambridge monetary theory until Lavington (1921) suggested that they might also hold money as a protection against the uncertainties to which their participation in financial markets exposed them. Keynes developed this insight in the Treatise, when he dealt with what he called the financial circulation. Specifically, he related changes the amount of money that agents would want to hold for speculative (here I use the vocabulary of the General Theory) purposes to their swings between moods of pessimism and optimism. In times of pessimism, investment would shrink, and savers would simultaneously build up money holdings in the financial circulation. When optimism returned, investment would pick up, and some of the funds needed to finance it would simultaneously be released from the financial circulation into the industrial circulation, where they would circulate in exchange for currently produced output. Crucially, these monetary movements would dampen the very swings in the market rate of interest needed to match those in the natural rate induced by successive waves of optimism and pessimism, and hence interfere with the mechanisms whereby investment might be kept in harmony with the economy's underlying saving rate.

This analysis too was pushed further in the General Theory. There, Keynes argued that agents always have the option of holding money as a store of wealth, and that money, being the economy's means of exchange and hence the most liquid (easily marketed) of all assets, they would demand a premium in order to part with it. Hence, the very presence of money in the economic system put a positive floor under the rate of interest, so that when investors "animal spirits” were depressed, it could not fall low enough to generate the volume of investment needed to absorb the economy's full-employment level of savings.

\section{VI - The Multiplier}

The General Theory was by no means the first work to argue that: (a) the co-ordination of saving and investment at full employment by the rate of interest might break down because of the working on the monetary system; and that (b) this breakdown would likely result in unemployment. Earlier work, however, had failed to explain just how (b) in fact followed from (a). For example, the Treatise on Money itself had presented many verbal arguments about why output and employment might fluctuate as waves of optimism and pessimism caused the natural rate of interest to move away from the market rate, but that book's underlying theoretical framework nevertheless yielded cycles only in prices. That was because, as Keynes's younger colleagues at Cambridge had been quick to point out, the framework had implicitly assumed output and employment to be constant. In the General Theory, Keynes filled this gaping hole in his previous analysis with the multiplier, a mechanism which he did not originate, but for which he found a new and profoundly important theoretical use. 
The idea that cumulative spillovers among firms, industries and even sectors of the economy, might be a feature of economy-wide variations in output and employment made sporadic appearances in Classical economics from the late $19^{\text {th }}$ century onwards, and attracted increasing attention the 1920s, when the likely effectiveness of using variations in government spending on public works as a countermeasure to unemployment was frequently debated. The analysis of spillover effects remained disturbingly vague, however, inviting ridicule even from staunch supporters of the policies themselves. Pigou, for example, was still suggesting as late as (1933) that some arguments seemed to imply that, were the government to spend but one extra pound on increasing employment, that sum would be spent and re-spent in a never ending sequence until full employment had been achieved.

Richard Kahn, Keynes’s younger colleague and sometime student, had already played a prominent role in criticising the theoretical structure of the Treatise, and it was he who finally put the analysis of spillovers onto a firm foundation and simultaneously disposed of this reductio ad absurdum. In (1931) he suggested that there would be leakages at each step in the sequence of expenditures: only a fraction of any injection of funds aimed at putting the unemployed to work would be re-spent by its recipients in ways that would put others to work, only a fraction of this already reduced amount would be spent at the next round, and so on. The effects on employment of the initial expenditure would certainly be multiplied by spillovers, therefore, but the multiplying factor would be finite, its size varying inversely with fraction of expenditure that leaked away at each stage of the process.

Kahn analysed the creation of employment, and emphasised leakages from the multiplier sequence that arose because the government would no longer be obliged to pay unemployment relief (the dole) to newly employed workers, and because some of the expenditures of the latter would be directed at imports rather than domestic production. It was left to the Danish economist Jens Warming (1932) to restate the basic argument in the form in which Keynes would then use it. ${ }^{5}$ Warming suggested that the multiplier was better understood if formulated in terms of income rather than employment, because the critical leakages in the process were not those that Kahn had emphasised, but rather arose from the tendency of households to save a fraction of any income they received, an issue that Kahn had only touched on. For example, said Warming, if households saved 25 per cent of any increment to their income, and if this was the only leakage from the system, then the multiplier process would result in any new injection of government expenditure creating an increase in the economy’s output four times bigger than that injection.

The emphasis on saving in Warming's version of the multiplier process was crucial in enabling Keynes to bring together his ideas about the instability of investment behaviour and its dependence on animal sprits, and about the role of uncertainty in creating liquidity preference, the key ingredients of his case for the failure of Say's law to apply in a monetary economy, into

${ }^{5}$ Keynes referred only to Kahn the General Theory. Warming's paper appeared in the Economic Journal, of which Keynes was editor, so it is hard to believe that he was unaware of it, as Neville Cain (1979) pointed out. 
a coherent account of how, nevertheless, such an economy coped with the problem of coordinating savings and investment. If households saved a stable fraction of any increment to their income, then a fall in investment spending would set in motion a downward multiplier process that would continue until income had contracted sufficiently to ensure that savings once again just matched investment.

Thus, the central theoretical revelation of the General Theory was that, in a money economy, variations in income and employment, not in the rate of interest, are the primary factor co-ordinating saving and investment. At the same time, there seemed to be no reason why the level of investment would, except by chance, be sufficient to require the volume of savings that the economy would generate at full employment. Indeed, in mature economies such as Keynes took those of Europe and the United States to be in the 1930s, the availability of profitable investment projects was bound to be low and shrinking, animal spirits were likely to be permanently depressed, effective demand would fall short of the economy's capacity to produce goods and services, unemployment would be chronic, and far from being a symptom of some kind of disequilibrium soon to be eliminated by market forces, it would also be an equilibrium phenomenon.

Keynes's policy recommendations, which he developed only briefly, followed immediately: it was the role of government to fill, with its own expenditure, the gap between the level of investment required to generate full employment and that which animal spirits alone would induce. There was nothing new about recommending increased public expenditures in1936, but the foundation that Keynes provided for this advice, embedded as it was in a new theory that challenged the relevance of Say's Law to the workings of a monetary economy, was of the highest originality.

\section{VII - The Success and Simplification of Keynesian Macroeconomics}

The General Theory's rapid success owed much to the intellectual support it provided for an already popular approach to policy. In the early 1930s, another explanation of the economic troubles of the times, also grounded in an analysis of the workings of the monetary system that derived from Wicksell, had begun to capture many imaginations. But Austrian theory, as it was known, yielded nihilistic policy conclusions. ${ }^{6}$ It argued that credit creation by the banking system enabled firms to command the production of investment goods without any voluntary act of saving on the part of households, that this command could only be sustained at the cost of ever-rising inflation, and that when the process came to its inevitable end in economic crisis, the economy would be burdened with stocks of unfinished capital equipment and hence unable to satisfy the demand for consumption goods. This imbalance could only be righted over time by labour force growth and depreciation of the capital stock. Any attempts by activist governments

${ }^{6}$ Friedrich von Hayek (1931) and Lionel Robbins (1934) are key expositions of Austrian theory, which is discussed in more detail in Laidler (1999). 
to hurry matters along would be destructive. Expansionary monetary impulses had caused the problem in the first place, so more of the same was the last thing needed; the capital stock was already over-expanded, so government sponsored investment would worsen the situation; and there was no point in taking measures to stimulate consumption expenditure when the economy was already unable to meet existing demands.

It is easy enough nowadays to find theoretical weaknesses in this Austrian story, most of which stem from its protagonists' tendency to treat logical possibilities as if they were logical necessities, but it was based on apparently rigorous economic theory (by the standards of its time) and it also provided intellectual respectability to arguments for a "hands-off” policy towards the Depression that were extremely popular in the financial community, and conservative political circles more generally, on both sides of the Atlantic. For economists who also wished to be policy activists, therefore, the arrival of Keynes's alternative theoretical vision was an event of singular importance, and it quickly drove Austrian ideas into professional obscurity.

Another factor contributed to the success of Keynes's analysis, however: namely, that its essential properties seemed capable of formal expression in terms that were only a very little more difficult to grasp than supply and demand analysis. The simplifications that enabled its message to be so expressed, though they had Keynes's own sanction, nevertheless distracted attention from the key role that the General Theory attributed to the facts of monetary exchange and their consequences for the economic system's behaviour, and they helped to ensure that macroeconomics began to lose sight of this essential feature of his contribution, as we shall now see.

Underlying Keynes's analysis of the role of money in disrupting the co-ordination of saving and investment by the interest rate were informational problems associated with the simple fact that economic activity takes place over time and that actions have to be based on expectations. Before 1936, many, including himself in the Treatise on Money, had treated the evolution of expectations as integral to the processes generating cyclical swings in unemployment, and the passage of time was thus always a central feature of their discussions, but a formal treatment of these matters was prevented by the lack of a technical apparatus that was up to the task. In 1936 Keynes dealt with this problem by resorting to a ruthless simplification: he divided expectations into two categories: short-term, and long term, and then proceeded "as if” the former were always fulfilled, and the latter exogenous. In so doing, he created a manageable framework for analysing how an economy in which choices were coordinated by output changes rather than price-level or interest rate movements would respond to various shocks

But, paradoxically, that analytic framework now abstracted from the passage of time, and hence from any raison d'etre for the very phenomena that were in the first place responsible for output changes rather than interest rate movements being at the heart of a monetary economy's co-ordination mechanisms. It thus only partially encompassed the ideas of the General Theory, but because it proved amenable to algebraic and geometric expression in the form of the so- 
called IS-LM (investment $=$ saving, liquidity preference $=$ money stock) model, it in due course became the workhorse of the textbooks. ${ }^{7}$ IS-LM could be used to demonstrate some of Keynes's key conclusions: depressed "animal spirits" would lead to a low level of income and employment; monetary policy could offset this only to the extent that the interest rate could be driven down; a fiscal response would be more reliable; etc. But the reasons why the equations of the system took the forms needed to produce such results could not be developed within it, and other forms seemed just as admissible.

Some of these alternatives, moreover, yielded very "Classical” results, in the sense of showing that Say's law might hold after all, even in the presence of money. The best known of these alternatives, developed in various degrees of detail by Gottfried von Haberler (1937), Pigou (1943) and Don Patinkin (1948) among others, involves the system's properties when it is postulated that (a) the price level will fall if the level of income is below full employment, (b) the nominal supply of money is given, and (c) expenditure increases with the real purchasing power of that given nominal money supply. On these assumptions, for a given level of "animal spirits" and degree of liquidity preference, and with any possibility for expectations to respond to falling prices eliminated by assumption, the system's only equilibrium is at full employment. Hence it appears to show that there is no fundamental "flaw" in the workings of the market economy. But what this result really demonstrates is that if a model abstracts from the fact that economic activity takes place in real time, and hence from all the forces which make monetary exchange essential in any actual economy, it will also abstract from the factors the can cause Say's law to fail.

As a critique of Keynes's contribution to macroeconomic analysis, this is hardly an earthshattering result, then, useful though it is in confirming his insights about just where the fundamental monetary problems he thought worthy of his attention reside; but it was precisely this result that yielded the myth - once termed a "useful fiction" by Paul Samuelson - that Keynes's explanation of unemployment relied on the assumption of money wage stickiness; more important, it provided a basis for the belief, widely held even among those who have taken the trouble to read the General Theory, that even though Keynes had indeed claimed that wage stickiness was irrelevant, he had been mistaken to do so. Small wonder that Keynes's radical younger colleague Joan Robinson would refer to the IS-LM model as “Bastard Keynesianism”, or that, in (1968) Leijonhufvud would draw a clear distinction between Keynesian Economics and the Economics of Keynes, and argue that macroeconomics would do well to abandon the former and begin to rebuild itself on a foundation drawn from the latter.

${ }^{7}$ The best single account of the process whereby "Keynesian Economics" came to be encapsulated in the so-called IS-LM model is Warren Young (1987). The discussion that follows here is partly based on Roger Backhouse and Laidler (2004, forthcoming) 


\section{VIII - Monetarism and After}

Leijonhufvud' s plea was to be ineffective. Instead, the monetarist counter-revolution would take centre stage, not least because by the 1970s, inflation was emerging as the central problem facing market economies everywhere, and because monetarism was every bit as much devoted to the economics of inflation as the General Theory had been to the economics of depression. Even so, two other books of Keynes's, namely his (1923) A Tract on Monetary Reform and (1940) How to Pay for the War exerted a direct influence on monetarism's early evolution. In both of them, Keynes made a vigorous case for price level stability as a necessary condition for the smooth functioning of a fully-employed market economy, and argued that if the money supply was expanded at a rate significantly in excess of the economy's potential rate of real growth, inflation would result. But he also explained that fiscally hard pressed governments might nevertheless be driven to print money as a means of balancing their budgets. These arguments had considerable resonance when inflation became a pressing policy problem in the 1960s and 1970s, and the monetarists paid attention to these other books of Keynes's, particularly the Tract.

How to Pay for the War had also had an indirect influence on Milton Friedman's work in the 1940s. In it, Keynes argued that, with the onset of war, Britain's problem was no longer to find employment for surplus resources, but to choose among alternative uses for scarce ones. The requirements of the war had created an inflationary gap between the economy's demand for goods and services and its capacity to produce them. Britain's 1941 budget was based on Keynes's analysis of how to bridge that gap without resort to the printing press, and its ideas made a considerable impression Friedman, who, without being aware of their origins in Keynes's work, gave them great play in his first two articles on inflation (1943, 1942 rev.1953)

The eclipse of Keynes’s (1936) ideas by monetarism in the 1960s and 1970s was only partly due to a change in the prevailing economic climate, for Friedman and Anna Schwartz's Monetary History of the United States (1963) challenged some of them on their own ground, and persuasively so too. In Keynes's view, the Depression in the United States had begun with a collapse of animal spirits, and had persisted because investment opportunities remained limited in a maturing economy; falling wages and prices had not prevented the economy's collapse, nor had, or could, expansionary monetary policy, because it could not drive the rate of interest low enough to revive investment: hence the case for fiscal policy as a means to sustained recovery. For Friedman and Schwartz, on the other hand, the Depression was mainly a matter of illconceived monetary policy: after an initial downturn, perhaps itself caused by a mild monetary tightening, adjustments to wages and prices had failed to restore output and employment because the quantity of money had then collapsed in the face of a series of preventable bank failures. Output had barely responded to expansionary monetary policy when it was tried, notably in 1932, because it had not been expansionary enough. ${ }^{8}$

${ }^{8}$ Friedman and Schwartz's treatment of the Depression in the US resembles that of Lauchlin Currie (1934), which was, as he acknowledged, influenced by Hawtrey’s cycle theory. 
This re-interpretation of the Great Depression was supported by copious empirical evidence, and it implied a deeply conservative message, quite contrary to that of The General Theory: namely, that the Depression provided no evidence that mechanisms inherent in a monetary economy required that it be subjected to continuous and rather large scale government intervention. Such an economy was reliably self-regulating so long as monetary policy makers refrained from creating chronic excess demands or supplies of money. In either circumstances, Say's law might be violated - along the lines that Mill had hinted at in 1844, it might be noted as friction-prone markets tried to eliminate the excesses in question, but there was no reason to follow Keynes in arguing that, in a monetary economy, the inter-temporal co-ordination mechanism was chronically prone to failure.

This argument of Friedman and Schwartz it proved extremely influential, but Monetarism was soon to cede its important place in macroeconomics to New-classical economics, (see, eg.. Lucas and Sargent 1978), with whose advent, the last vestiges of Keynes's economics would disappear from the area's mainstream. Initially, New-classical economics seemed to be no more than a mathematically rigorous restatement of monetarism, but. though it supported the same conservative policy stance, it also introduced two new and radical theoretical doctrines. First, the rational expectations idea had it that agents' expectations about the future should be treated "as if" based on as much knowledge of the structure of the economy and the time series properties of the shocks impinging upon it as was available to the economist building the model used to analyse their behaviour. Second, the notion of market clearing required that such models should assume that supply and demand were kept continuously equal to one another in all markets.

Within New-classical economics, therefore, fundamental uncertainty, failures of Say's law, and the factors differentiating money and barter economies were ruled irrelevant by methodological fiat, and macroeconomics became completely detached from the ideas that had formed the subject of Keynes's General Theory, and unable, even unwilling, to discuss them. Ironically, it took on the very features that Keynes had so unfairly attributed to Classical economics, prior to criticising it. At the time of writing, New-classical economics is under challenge from a body of work (see, eg. Michael Woodford 2003) whose main differentiating characteristic is the deployment of money-wage and price stickiness postulates. This new body of work has therefore done nothing to move macroeconomics back towards analysing the theoretical issues that were central to it when it emerged as a distinct sub-discipline; indeed the universal acceptance of its self-adopted label - New Keynesian economics - suggests that contemporary macroeconomics has now forgotten what those issue were. 


\section{References}

Backhouse R., and D. Laidler 2004 What was lost with IS-LM History of Political Economy (Conference Supplement) forthcoming

Bateman, B. W. 1996 Keynes’s Uncertain Revolution Ann Arbor, Univ. of Michigan Press

Cain, N. 1979 Cambridge and its revolution: a perspective on the multiplier and effective demand Economic Record 55 (June) 108-117

Currie, L. 1934 The Supply and Control of Money in the United States, Cambridge MA, Harvard University Press

Friedman, M, 1943 Methods for predicting the onset of “inflation" in C. Shoup, M. Friedman, and R. P. Mack, Taxing to Prevent Inflation: Techniques for Estimating revenue Requirements, New York, Columbia University Press

Friedman, M. 1942 Discussion of the inflationary gap, American Economic Review, rev. and repr. Essays in Positive Economics Chicago, University of Chaicag Press, 1953

Friedman M., \& A. J. Schwartz 1963 A Monetary History of the United States 1867-1960 Princeton, NJ., Princeton University Press, for the NBER

Haberler, G. von 1937 Prosperity and Depression, Geneva, League of Nations

Hawtrey, R. G. 1913 Good and Bad Trade, London, Constable

Hayek, F. A. von 1931 Prices and Production, London, Routledge

Kahn, R. F. 1931 The relation of home investment to unemployment Economic Journal 41 (June) 173-198

Kates, S. 1994 The Malthusian origins of the General Theory: or, how Keynes came to write a book about Say's law and effective demand, History of Economics Review 21 (Winter) $10-20$

Keynes, J. M. 1921 A Treatise on Probability, London Macmillan

Keynes, J. M. 1923 A Tract on Monetary Reform, London, Macmillan

Keynes, J. M. 1930 A Treatise on Money (2 Vols.) London, Macmillan

Keynes, J. M. 1936 The General Theory of Employment, Interest and Money London, Macmillan 
Keynes, J. M. 1940 How to Pay for the War, London, Macmillan

Laidler, D. 1999 Fabricating the Keynesian Revolution, Cambridge, Cambridge University Press

Lavington, F. 1921 The English Capital Market London, Methuen

Lavington, F. 1922 The Trade Cycle London, P. S. King \& son

Leijonhufvud, A, 1968 On Keynesian Economics and the Economics of Keynes, Oxford, Oxford University Press

Leijonhufvud A. 1981 The Wicksell connection in Information and Co-ordination, Oxford, Oxford University Press

Lucas, R. E. Jr \& T. J. Sargent 178 After Keynesian macroeconomics, as repr. in R. e. Lucas Jr \& T. J. Sargent (eds) Rational Expectations and Econometric Practice London, George Allen \& Unwin 1984)

Malthus, T.R.. 1820 Principles of Political Economy, repr.(with Ricardo's Notes) P. Sraffa (ed.) Works and Correspondence of David Ricardo Vol. 2, Cambridge, Cambridge University Press for the Royal Economic Society, 1956

Marshall, A. 1871 Money, as pub. in J.Whittaker (ed.) The Early Economic Writings of Alfred Marshall 2 vols., London Macmillan

Marshall, A, and M. P. Marshall, 1879, Economics of Industry London, Macmillan

Mill, J. S 1844 On the influence of consumption upon production, in Essays on Some Unsettled Questions in Political Economy, London, Longmans, Gree, Reader \& Dyer $\left[2^{\text {nd }}\right.$ ed. 1874]

Mill, J. S. 1848 [ $7^{\text {th }}$ ed 1871] The Principles of Political Economy with Some of their Applications to Social Philosophy repr. in 2 vols. ed. J. M. Robson, Toronto, University of Toronto Press, 1965

Patinkin, D. 1948 Price flexibility and full employment, American Economic Review 38n (Sept.) 534-564

Pigou, A. C. 1912, Wealth and Welfare, London, Macmillan

Pigou, A. C. 1933 The Theory of Unemployment, London, Macmillan

Pigou, A. C. 1943 The classical stationary state, Economic Journal 53 (June) 343-351 
Ricardo, D 1817 \{ $3^{\text {rd }}$. ed. 1821\} Principles of Political Economy and Taxation, repr. P. Sraffa (ed.) The Works and Correspondence of David Ricardo, Vol. 1 Cambridge, Cambridge University Press for the Royal Economic Society, 1956

Robbins, L. C. 1934 The Great Depression London, Macmillan

Smith, A 1776 An Inquiry into the Nature and Causes of the Wealth of Nations, London

Thornton, H. 1802 An Enquiry into the Nature and Effects of the Paper Credit of Great Britain, London

Warming, J.1932 International difficulties arising out of the financing of public works during a depression, Economic Journal 42 (June) 211-224

Wicksell, K. 1898 Interest and Prices, as tr. R. F. Kahn, London, Macmillan for the Rpoyal Economic Society 1936

Woodford, M. 2003 Interest and Prices: Foundations of a Theory of Monetary Policy,

Princeton, NJ., Princeton University Press

Young, W. 1987 Interpreting Mr. Keynes: the IS-LM Enigma UK, Polity Press 